\title{
Development of the innovative economy based on the transformation of the knowledge- intensive enterprises
}

\author{
Tatyana Kurina* \\ Russian New University, Moscow, Russia
}

\begin{abstract}
In modern conditions of economic transformation, the task of innovative development of the economy of the Russian Federation is the use of advanced technologies in the development of high-tech industries. Russia's entry into the top five world economies will be facilitated by its breakthrough into new areas of knowledge and technology, accelerating the processes of the country's integration into the world economy. In the search for a solution to this problem, it is necessary to consider the latest trends in the development of the world economy, which are manifested in the context of globalization and the transformation of knowledge into a leading factor in economic growth. These trends include the formation and development of an innovative economy of a new type based on the transformation of the knowledge-intensive sector. As part of ensuring this ambitious goal, it is required to build a new innovative infrastructure that can integrate the interests of science, education, government and business, create high-tech industries and integrate into the knowledge-intensive sector, which, in turn, will ensure the accelerated innovative development of the economic system. A knowledge-based economy is a qualitatively new economic system in which production processes, organizational forms of enterprises and economic ties between them, the economic mechanism and property relations are largely transformed under the influence of technological factors. One of the strategic directions of Russia's economic development is modern science, innovative education and a complex of high-tech industries. This study is based on the fact that in Russia there is a change in the nature of technological and innovative development, considering competitive advantages. In this regard, the most important task of the modern period of the formation of an innovative economy of a new type is the need to search for new drivers to realize the possibility of the country's entry into the top five developed countries of the world by 2024 . The relevance of this study is due to new approaches to innovative development in the context of the transformation of the knowledge-intensive sector, which is formed in partnership between the state and business.
\end{abstract}

\footnotetext{
*Corresponding author: tk19@ rambler.ru
} 


\section{Introduction}

Innovative development in the context of the transformation of the knowledge-intensive sector acts as a new organizational form of strategic management, including the intensification of innovative activity in the context of Russia's entry into the top five world economies, substantiation of the principles and directions of economic development in the context of integration into the world system, methodological approaches to forecasting the development of economic systems with considering the factor of resource availability. The research, generalizations and conclusions of the author expand the understanding of innovative development, which manifests itself at the level of elaboration of the problems of the strategy of innovative development in the context of the transformation of the knowledgeintensive sector in the theoretical aspect and methodological approach. As a result, the concept of innovative development of a new type of economy was formulated on the basis of the formation of an efficient innovation mechanism through the inclusion of conceptual foundations for the involvement of unused resources.

\subsection{Development of an innovative economy in a new technological order}

The modern world is a dynamic system at the stage of globalization, associated with the expansion of international integration, the creation of regional integration associations.

The modern economic paradigm as the main instrument of systems is exposed to the danger of wasteful consumption of resources caused by market competition.

The concept of sustainable development requires a new methodology for the study of economic processes, modern innovative approaches, assessment tools. [1, p. 12]

The concept of sustainable development of socio-economic systems is a new paradigm, the main content of which is the global unregulated economy and the need to search for integrated solutions to social, economic and environmental development goals.

The outlined path of breakthrough development is a variant of the development of the national economy, which is based on economic growth, which is realized through the formation of socio-economic systems that are integrated both at the meso- and macro-levels. [2, p. 22]

In a modern economy, innovation processes are critical at all levels.

The tasks of further innovative development are reduced to stimulating the systemic development of high- and medium-tech industries; ensuring the growth of R\&D costs; development of knowledge-intensive service industries; staffing the knowledgeintensive sector.

The size of the sector of medium and high-tech industries suggests that it can soon form stable financial flows to replenish the budgets of all levels and create a new quality of life for society (a new type of economy). Systemic transformation of all elements of the national economy can give a new qualitative effect. [3, p. 11]

The socio-economic system, changing under the influence of the external environment, retains its essence: material production, labor and natural resources, as well as their main functions, including the implementation of material production, non-production products, the transformation of minerals into final products. [6, p. 31]

Each component of the objective and subjective subsystems can be represented by the corresponding elements reflecting the structure of production, financial and informational connections that mediate the movement of various types of resources or flows. The number of elements and connections is determined by the level of the analyzed system.

Hence, material production and the non-productive sphere are closely interrelated areas of labor activity of individuals and societies. 
As known, material production forms the material basis for the functioning of the nonproduction sphere, covering a wide variety of activities: from the sphere of management, defense and national security to social infrastructure, which includes the provision of social, communal and other services to the population.

Thus, the satisfaction of the aggregate needs of society is carried out through the functioning of both spheres of labor activity of society and individual individuals.

Let us list the components of the basic structure of the innovation system.

Representatives of fundamental and applied science as generators of ideas and sources of innovation (academies of sciences, research institutes, laboratories) and scientific and educational institutions as suppliers of personnel (universities, colleges, technical schools), which in general form forms the U-component of this study.

The business sector, which is made up of a set of innovatively active large and mediumsized industrial enterprises, small innovative companies, start-ups - the B-component.

The public sector as the developer of the regulatory framework for determining the legal contours of intellectual property, the main regulator of the relationship of all participants through the legislative system, as well as a lever that determines the organizational foundations of the functioning of the subjects of the regional innovation system, its infrastructure support. [8, p. 14]

The main goal of the current stage of transformation of the Russian economy is to enter the top five world economies in real time, it is necessary to use the latest technologies, human potential, and innovative activities.

Under the influence of globalization, approaches to the innovative development of the economy are also changing.

Dynamic transformative processes of material production and distribution are due to the interaction of the following components:

- social-and-cultural components - reflect the cultural background of the development of science in the country, priorities, intellectual traditions;

- human resources of a knowledge-based economy - contribute to the creation and dissemination of new scientific knowledge, preserve scientific traditions;

- intellectual and informational component (availability of scientific knowledge);

- structural components (knowledge-intensive types of services that form the demand for scientific knowledge).

The concept of a knowledge-based economy is considered by the author as a system of ways to solve problems, including the emergence of new segments in the innovation system of the Russian Federation: [9, p. 22]

- the formation of the "economy of the future";

- high-tech development of traditional industries;

- inclusive innovation.

The transformation of the knowledge-intensive sector is based on the doctrine of innovative development, which mediates an increase in competitiveness and modernization of the economy.

\subsection{Innovative development of the economy within the framework of the program-targeted approach}

The program-targeted approach reflects the interaction of the institutional sectors "state science - business". Organizational links of subsystems of the socio-economic system determine the directions and composition of information flows that characterize the state of each division of the organization and its external environment, and reflect the parameters and results of its activities, allowing one to choose a strategy for the development of subsystems 
and organizations as a whole. In this case, the structure of the information scheme corresponds to the ongoing management processes.

Analysis of the qualitative characteristics of the identified situations, which arise as a result of the interaction of the subsystems of the organization with each other, the interaction of subsystems of the external environment and the interaction of subjects of the economy and the external environment, makes it possible to highlight the key factors in choosing a development strategy.

The organization scheme of the management process, developed within the framework of management theory, includes the choice of a strategy for resolving a situation or problem.

In other words, each subject of the economy makes a choice: to solve the problem that has arisen by reacting to current events, or to adapt its activities to the existing socioeconomic conditions, or to use a strategy that links the present state of the organization with its future. It is possible to use the provisions of the listed strategies at the same time or their combination regarding the problems to be solved and control subsystems. [10, p. 18]

The model of the formation of the high-tech sector is shown in the figure.

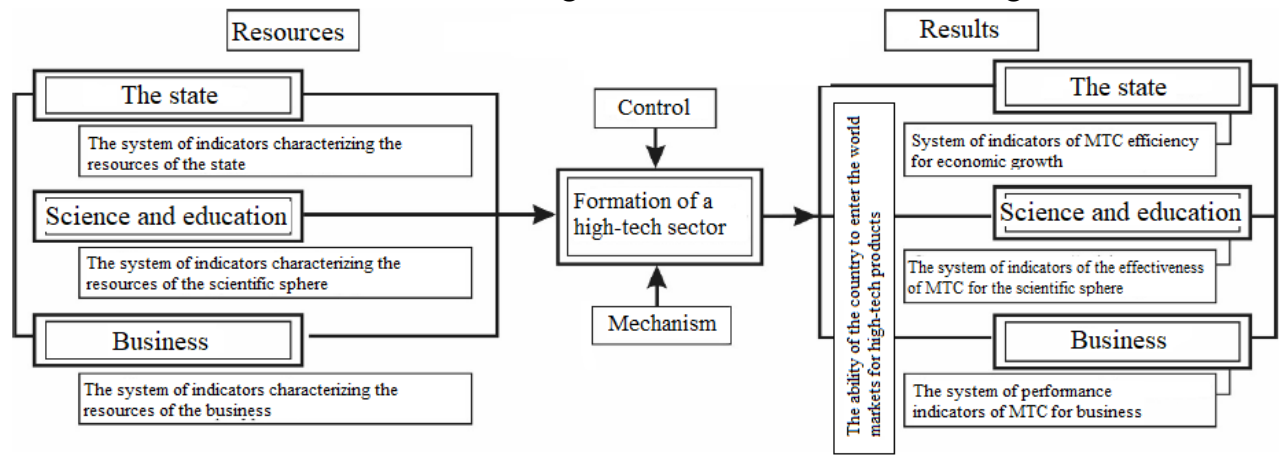

Fig. 1. Model for the formation of a high-tech sector.

The organization scheme of the management process, developed within the framework of management theory, includes the choice of a strategy for resolving a situation or problem.

In other words, each subject of the economy makes a choice: to solve the problem that has arisen by reacting to current events, or to adapt its activities to the existing socioeconomic conditions, or to use a strategy that links the present state of the organization with its future. It is possible to use the provisions of the listed strategies at the same time or their combination regarding the problems to be solved and control subsystems.

When developing a program as a management tool, it is necessary to focus on certain criteria. Such criteria can be indicators of strategic and tactical efficiency, orienting the system's subdivisions to meet the aggregate demand for certain types of goods and services, aimed at increasing the profitability of production and commercial activities, capitalizing economic entities and increasing incomes of individuals. [11, p. 23]

To assess the efficiency of the organization of management processes, indicators are used that characterize the relationship and interaction of goals, tasks and functions that determine the composition and interaction of subsystems. Such differentiation is needed in order to identify the contribution of all elements and the quality of each subsystem in the management process.

The plan defines the necessary resources, economic entities and societies, whose activities will be aimed at achieving specific goals.

With the help of a program (plan) as a tool to achieve a global goal, it is possible to coordinate the actions of the system's divisions, analyze intermediate results, compare them with planned ones and apply corrective measures in time. Herewith, the efficiency of all work depends on the interest of individuals and the entire team. [12, p. 31] 
Therefore, the plan should include measures to motivate and stimulate the implementation of goals set at each level. Within the framework of organizing the activities of the systems, the practice of strategic planning using indicators of final results has not found proper application. Many target indicators and indicators of achievement of objectives are chosen incorrectly and cannot be quantified.

\subsection{Innovative priorities for economic development based on the transformation of the knowledge-intensive sector}

The transition to an innovative type of economic development is the main goal of state policy in the field of science and technology formation.

The guidelines for the strategy of innovative development of Russia in the context of the country's entry into the top five world economies are shown in the figure.

The benchmark is the formation and development of market structures that contribute to the successful functioning of innovation and the dissemination (commercialization) of R\&D results.

This benchmark should be considered as the creation of general economic conditions and conditions of the business environment, support for competition, including in the resource markets. [18, p. 12]

In a narrow sense, this priority means the formation of the NIS infrastructure, a network of organizations that provide services to the subjects of innovation.

Currently, a scientific and technological cycle has been formed: "Research - development - transfer - production - consumption".

One of the functions of the scientific and technological cycle are $R \& D$, which are performed by universities, research centers, design bureaus and other organizations that generate new knowledge and innovations and participate in the commercialization of R\&D results $[19$, p. 16].

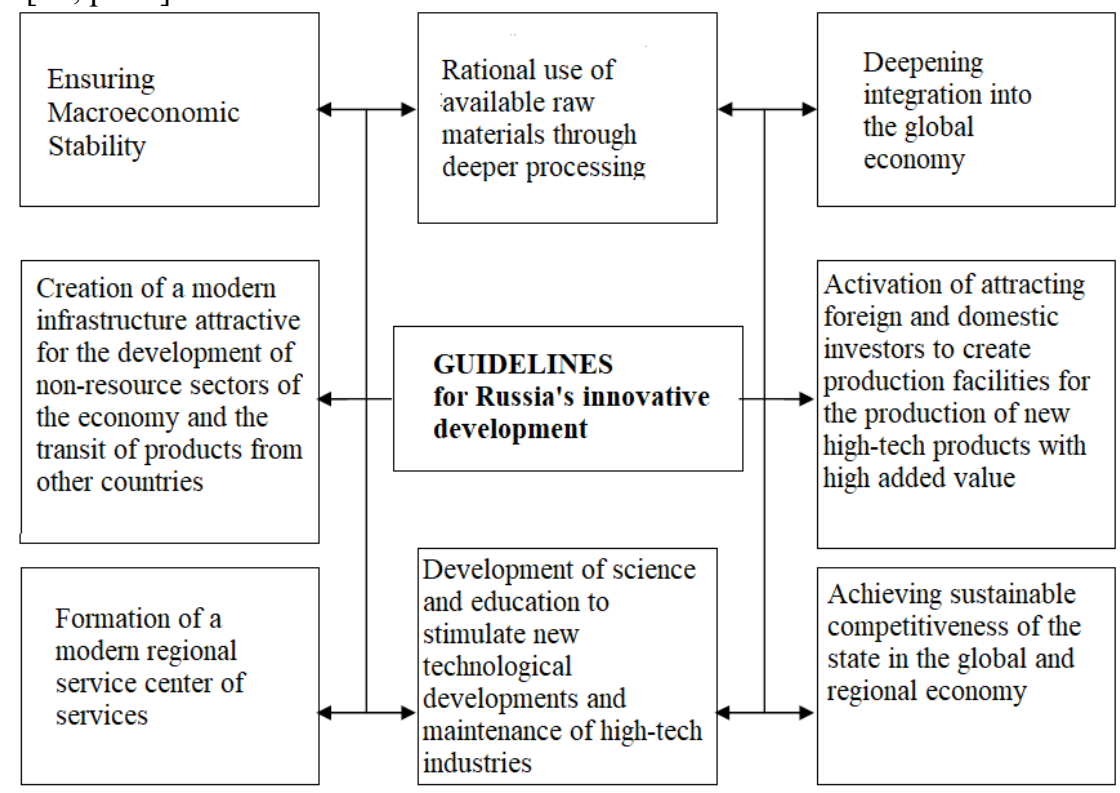

Fig. 2. Priority strategies for innovative development.

Overcoming the existing problems should be among the top-priority tasks, the solution of which will ensure the formation of the NIS. However, in addition to research centers, the 
structure of NIS includes various organizations with functions that implement not only innovative activities, but also the dissemination of information and R\&D results. Thus, the efficiency of the introduction of innovation at a particular enterprise depends on external factors, primarily on the quality of raw materials and materials, as well as on the technology used in companies that consume the products of this enterprise. [20, p. 8]

Key areas of innovative development are shown in Figure 3.

The information base is an element of the innovation infrastructure.

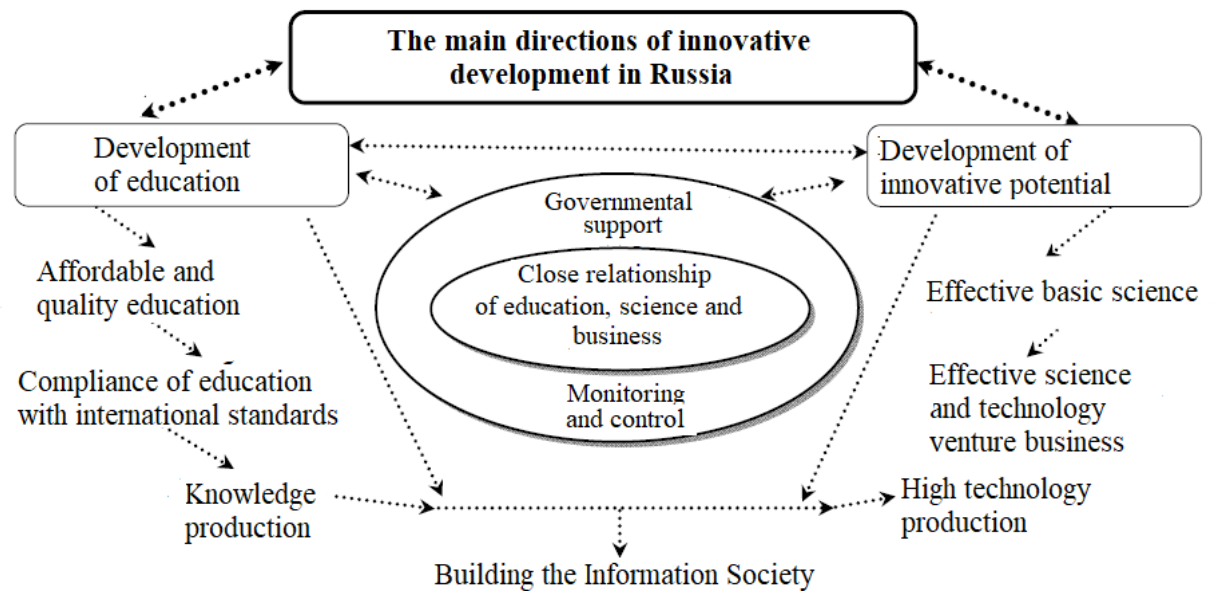

Fig. 3. The main directions of innovative development.

Insufficient use of information technology to support innovation is supported by low demand for innovation.

The formation and development of commercialization institutions are becoming a key factor in the success of the implementation of systemic measures. In all countries that have embarked on a course for innovative development, the commercialization of R\&D results is one of the fundamental tasks of the state.

The benchmark is the restructuring and innovative development of the manufacturing industries.

The modern industry of Russia is represented by large and dynamically developing industries associated with external markets that have access to foreign direct investment, and with foreign multinational companies, which dominate in terms of technology transfer and domestic demand for innovation. [21, p. 5]

Almost all branches of industry have been identified as priorities, which does not correspond to the essence of the concept of "priority".

In our opinion, priority for the innovative development of the economy is only a narrow list of manufacturing industries with a capacious domestic market and potential opportunities to enter foreign markets. Among the priorities we include mechanical engineering, chemical and food industries.

Moreover, only in mechanical engineering there are several segments, e.g., agricultural, transport, oil and gas and electrical engineering.

Thus, the priority sectors for diversification should be specified in terms of segments, based on the goals of diversification, resource endowment, market size, technological links with other industries, and, importantly, their diversification should lead to positive social consequences at the regional level.

The priority - the main resource for the innovative development of the economy should be human capital, which is the main component of the country's national wealth. 
Human resources are a key factor in innovative development. It is recognized that human capital has become the main resource for the innovative development of the economy and serves as the basic component of the country's national wealth. Naturally, the efficiency of using human capital depends on its quality.

The key task of the Russian education system is adaptation to new economic conditions and tasks, in particular those associated with the country's innovative development. One of the tasks is personnel training. The education system should keep pace with structural changes in the economy and structural transformations in the labor market, which requires the creation of a system of retraining and retraining of personnel, provide them with the opportunity to learn throughout their lives and enhance all components of the education system. [22, p. 31]

The priority is the development of resource-saving technologies.

An economy in which labor, material, natural and other resources are rationally used can be effective. This vision is largely consistent with the sustainable development model adopted by international organizations.

The diversification of the economy should be carried out in compliance with the principles of sustainable development: rational use of natural resources, prevention of environmental problems, reduction of the negative impact of anthropogenic load, integrated use of multicomponent natural resources.

The priority is to support innovative entrepreneurship.

This priority is aimed at reducing the level of concentration of innovation in large companies, increasing the role of small and medium-sized businesses in the process of accelerated diversification of the economy.

Banks rarely finance innovative projects, primarily those initiated by start-up companies, due to the high risks.

The efficiency of the introduction of innovation at a particular enterprise depends on external factors, first of all, on the quality of raw materials and materials, as well as on the technology used in companies that consume the company's products. Such interconnectedness of the results determines the feasibility of creating innovative clusters.

The priority is the technologies of the future in traditional industries as the most important condition for the growth of the competitiveness of the national economy.

The Russian industry is characterized by a structural imbalance, which is reflected in the dominance of the extractive industries.

It is proposed to take an increase in the share of manufacturing industries in the industrial structure as a priority of the strategy for innovative development of the economy. It is assumed that innovations will be aimed at technological modernization of existing industries, which will lead to diversification of manufacturing industries, focused primarily on the production of science-intensive products. [23, p. 25]

Priority - knowledge-intensive services - information and communication services, professional scientific and technical services, financial services, transport services, the development of digital services, high-tech medical services.

The strategy of innovative development of Russia can have the following vectors:

- implementation of a strategic course for diversifying the structure of the economy, overcoming its raw material orientation;

- ensuring the advanced development of sectors that create conditions for increasing the level and quality of life of the population;

- a significant increase in the competitiveness of products.

Accelerated diversification of the economy within the framework of the introduction of new industries using innovations requires the implementation of a set of systemic measures, among which the following are important: $[24$, p. 52] 
- creation of an innovative platform for ongoing consultations and development of cooperation between participants in innovative activities. Formation of an innovative platform will enhance the efficiency of spending budget funds;

- increasing the efficiency of the technology transfer (commercialization) process. The authorized state bodies are faced with the task of creating institutions that promote mutually beneficial exchange of technologies and information;

- development of the national innovation system;

- facilitating the process of co-innovation. This approach means cooperation of participants to develop innovations and exchange information.

\section{Materials and methods}

Materials and research methods are determined by the topic and the specifics of the tasks set, the solution of which requires an integrated approach. The research methodology is based on general scientific methods, principles and priority directions of innovative development in the context of integration into the world system, methodological approaches to forecasting the development of an innovative economy, considering the country's entry into the five strongest economies in the world, which makes a certain contribution to the development of the theory of an innovative economy, including the development of methodological the foundations of the formation of an innovative economy of a new type based on the transformation of the knowledge-intensive sector. The method of expert assessments is in the process of substantiating the methodology for the formation of an innovative economy of a new type.

\section{Literature review}

The innovative development of Russia pursuant to the needs of modern society is impossible without theoretical and methodological research.

The theoretical and methodological basis of this area of economic science was formed by the works of such researchers, as V.V. Akberdin, A.E. Varshavsky, E.A. German, V.E. Dementyev, A.G. Dmitriev, V. Ivanov, N.I. Komkov, E.O. Naumenko, O. A. Romanova, B. Twiss, J. Schumpeter et al.

The influence of scientific and technological progress on the development of economic systems and the reproduction of innovation and technological cycles, reflecting the change in technological structures in the economy, is revealed in the works of M.A. Bendikov, N.A. Ganichev, S. Glaziev, P.F. Drucker, A.A. Dynkin, V.L. Inozemtsev, M. Ya. Kazhdan, T.P. Kazakova, O.B. Koshovets, D.S. Lvov, E. Mansfield, D. Sanzhiev, D. Titov, L. Fedulova, V. Fridlyanova, I.E. Frolov, et al.

The adherence to the innovative economy to the principles of transforming the knowledge-intensive sector, practical approaches to the formation and development of innovative infrastructure, to the financing of innovations, the development of scientific and technical potential, the commercialization of developments are considered in the works of D. Gibson, L.M. Gokhberg, S. Gubanov, R. Grady, I.G. Dezhina, V.G. Zinova, A.B. Ilyin, J. Cunningham, I.P. Kondratyev, E.P. Konyukhovsky, M. Lokett, O.P. Lukshi, D.S. Lvov, V.I. Maevsky, D. Meisner, S.V. Markevich, V. Mau, A.G. Mokronosov, A. Moskovsky, L.V. Obolenskaya, T.S. Orlova, V.M. Polterovich, J. Pratt, M. Wright, O. Reznikova, O.A. Romanova, V.S. Sedov, M. Cervantes, D. Wiggins, K. Fitzgerald, N.E. Fomina, I.E. Frolov, D. Hecker, N. Shelyubskaya, A.I. Shinkevich, S. Schmid, P. Shoemaker, M. Ensley, E. Yasina et al. 
Recognizing the undoubted scientific validity and practical significance of existing approaches to innovative development, it should be noted that the existing works do not fully present the methodological research tools, the model of innovative development in the conditions of the country's entry into the five world economies has not been properly reflected. All this requires scientific generalizations and conclusions, the development of new methodological approaches to assessing innovative development in the context of the transformation of the knowledge-intensive sector.

\section{Results}

Currently, an innovative economy is an immanent attribute of the economic growth model. The key to the successful development of an innovative economy is the enhancement of innovation systems as an element of the national strategy.

However, the policy of innovative development of the Russian economy pursued in recent years has not yet yielded the desired result. The innovative component of manufactured products and their competitiveness are still at a low level, which is due to the lack of qualified personnel; low innovative activity of organizations; weak demand for innovative products, limited measures to stimulate the relationship between domestic science and business, etc.

\section{Conclusion}

An innovative economy of a new type is a new model of the Russian economy, reflecting a system of scientific knowledge about the principles and methods of influencing innovative development, in which a high final result is achieved pursuant to standards, indicators that produce innovative goods based on the fifth and sixth technological paradigms. An innovative economy of a new type contains such segments as the high-tech segment; segment focused on innovative development of traditional industries; a segment that includes a system of inclusive innovations; regional innovation systems.

On the basis of the identified trends in the socio-economic characteristics of Russia, on the one hand, and the availability of natural resources, on the other hand, an assessment of the potential for the development of a green economy was carried out.

The transition to a green economy in Russia contributes to the formation of an employment structure and investment environment in which new "green" jobs will be created in the sectors of the economy, covering a wide range of professional activities and specialties.

The directions of development of the innovative economy of the new type based on the activation of its key components have been proposed.

Thus, the theoretical and practical contribution, the empirical study presented in this work serve as reference points for bringing the Russian economy to a qualitatively new level pursuant to the transformation of the knowledge-intensive sector.

\section{References}

1. D.A. Kuznetsov, Peterburgskiy ekonomicheskiy zhurnal 1, 12 (2020)

2. Ye.N. Gorlacheva, Ye.M. Ivannikova, Ekonomika nauki 3, 22 (2019)

3. S.N. Larin, O.Ye. Khrustalev, YA.M. Yermakova, Nauka bez granits 9 (37), 11 (2019)

4. A.V. Polyanin, R.A. Markov, Vestnik Akademii znaniy 4 (39), 19 (2020)

5. N.N. Trofimova, Strategii biznesa 6, 5 (2020)

6. N. N. Trofimova, Vestnik GUU 18, 31 (2020) 
7. O.YA. Koleshchuk, Strukturnyye transformatsii kak prioritetnyy vektor razvitiya innovatsionnogo potentsiala mashinostroitel'nykh predpriyatiy, BI 1(504), 32 (2020)

8. N.V. Speshilova, D.A. Andriyenko, R.R. Rakhmatullin, Ye.A. Speshilov, Vestnik yevraziyskoy nauki 2, 14 (2019)

9. M.S. Oborin, Vestnik Nizhegorodskogo universiteta im. N. I. Lobachevskogo. Seriya: Sotsial'nyye nauki 4(60), 22 (2020)

10. A.V. Bragina, YU.V. Vertakova, A.V. Yevchenko, Organizator proizvodstva 1, 18 (2020)

11. I.A. Vasil'yeva, D.A. Komonov, M.V. Sazonova, Vestnik MGOU. Seriya: Ekonomika 1, 23 (2019)

12. L. N. Mishunina, YU. V. Yakubovskiy, Bol'shaya Yevraziya: Razvitiye, bezopasnost', sotrudnichestvo 3(1), 31 (2020)

13. A.A. Bakulina, E.S. Sokolova, National Security 5, 39 (2019)

14. R.V. Kuz'menko, Vestnik Instituta ekonomicheskikh issledovaniy 1(17), 8 (2020)

15. N.Ye. Ivanova, S.V. Kuznetsov, V.I. Udodova, Nauchnyy vestnik YUIM 1,25 (2020)

16. V.A. Seredokho, S.M. Makeyev, Innovatsii 9 (251), 42 (2019)

17. I.A. Gunina, I.V. Logunova, V.YU. Pestov, RSEU 1(44), 24 (2019)

18. Ye.A. Rogozina, T.V. Filimonikhina, N.D. Dmitriyev, Strategii biznesa 2, 12 (2020)

19. V.F. Maksimova, Innovatsii i investitsii 10, 16 (2019)

20. S. V. Kuregyan, G. V. Lepesh, I. V. Makarova, YU. V. Meleshko, O. D. Ugol'nikova, Ekonomicheskaya nauka segodnya 12,8 (2020)

21. A. I. Shinkevich, S. S. Kudryavtseva, M. V. Shinkevich, Vestnik GUU 8, 5 (2020)

22. A.A. Alabugin, N.A. Mukhortova, Vestnik YUUrGU. Seriya: Ekonomika i menedzhment 3, 31 (2019)

23. A.S. Zinchenko, Vestnik MGOU. Seriya: Ekonomika 1, 25 (2019)

24. V.A. Mizyun, S.A. Ishkil'dina, S.A. Yevdovskaya, Vestnik Saratovskogo gosudarstvennogo sotsial'no-ekonomicheskogo universiteta 4(78), 52 (2019) 